\title{
Paranasal Sinus Polyp
}

National Cancer Institute

\section{Source}

National Cancer Institute. Paranasal Sinus Polyp. NCI Thesaurus. Code C7486.

A polyp that arises from the paranasal sinus mucosa. Causes include allergic rhinitis, chronic sinusitis, and cystic fibrosis. It is characterized by the presence of edematous tissue infiltrated by inflammatory cells, including eosinophils. 